\title{
PENGUKURAN TULANGAN GEDUNG BPPT DENGAN COVERMETER ELEKTROMAGNETIK UNTUK KAJIAN KERENTANAN GEDUNG BERTINGKAT TERHADAP GEMPABUMI
}

\section{BPPT BUILDING REINFORCEMENT MEASUREMENT WITH ELECTROMAGNETIC COVERMETER FOR THE STUDY OF THE VULNERABILITY OF MULTI-STOREY BUILDINGS TO EARTHQUAKES}

\author{
Lian Yuanita Andikasari ${ }^{1}$
}

\begin{abstract}
Earthquake is a natural disaster that frequently happened in Indonesia. The Disaster Risk Reduction Technology Center, BPPT developed the Vulnerability Study of Multi-storey Buildings to earthquakes. This study was conducted on Building 2 BPPT. The important parameter in conducting the study is reinforcement data in the building column. One tool that can be used in measurements is electromagnetic covermeter. The measurement of this reinforcement is to measure the diameter of the reinforcement, how much reinforcement, and the average blanket of concrete that will be used for further data analysis.
\end{abstract}

Keywords: electromagnetic covermeter, earthquake, multi-storey building, reinforcement

\begin{abstract}
Abstrak
Gempabumi merupakan bencana alam yang akhir-akhir ini terjadi di Indonesia. Pusat Teknologi reduksi Risiko Bencana, BPPT melakukan Kajian Kerentanan Gedung Bertingkat terhadap gempabumi. Kajian ini dilakukan terhadap Gedung 2 BPPT. Parameter penting dalam melakukan kajiannya adalah data tulangan pada kolom gedung. Adapun salah satu alat yang dapat dipakai dalam pengukuran adalah covermeter elektromagnetik. Pengukuran tulangan ini untuk mengetahui berapa diameter tulangan, berapa banyak tulangan, dan selimut rata-rata beton yang akan digunakan untuk analisis data selanjutnya.
\end{abstract}

Kata kunci: covermeter elektromagnetik, gempabumi, gedung bertingkat, tulangan

Pusat Teknologi Reduksi Risiko Bencana - Badan Pengkajian dan Penerapan Teknologi, Jl. M. H. Thamrin No.8, Jakarta 10340, email: lian.yuanita@bppt.go.id

\section{PENDAHULUAN}

\subsection{Latar Belakang}

Berdasarkan data yang dihimpun oleh Kementerian Dalam Negeri dan rekapitulasi data Badan Pusat Statistik (BPS) tahun 2014, Indonesia memiliki luas wilayah daratan sekitar $1.910 .931 \mathrm{~km}^{2}$ (peringkat 15 terluas di dunia). Indonesia disebut juga sebagai Nusantara, yang terdiri atas pulau-pulau yang berjumlah lebih dari 17.000 pulau dengan wilayah yang terbentang sepanjang 3.900 mil dari Samudera Indonesia hingga samudera Pasifik. Jika merujuk pada data BPS, penduduk Indonesia pada tahun 2015 diprediksi mencapai
255.461.700 jiwa. Lebih dari separuh penduduk Indonesia bertempat tinggal di pulau Jawa (57 $\%$ dan hanya $1 \%$ penduduk tinggal di Kepulauan Maluku, Sumatera sekitar $22 \%$, sisanya Pulau Sulawesi $7 \%$, Pulau Kalimantan $6 \%$, Bali dan Kepulauan Nusa Tenggara sebesar 6\%, dan Pulau Papua $2 \%$ (Amri, 2016).

Pada tahun 2010, data dari BPS menunjukkan bahwa hanya 49,8 \% yang tinggal diperkotaan, dalam periode 5 tahun, yaitu di tahun 2015 proporsinya meningkat 3,5\% menjadi $53,3 \%$, persentase ini diprediksi semakin meningkat, menjadi 66,6 \%. pertumbuhan tersebut diprediksi sebesar sekitar 2,9 \% pertahun. Penduduk Indonesia diprediksi 
akan berkembang di wilayah perkotaan, artinya proporsi penduduk yang tinggal diperkotaan akan tumbuh lebih banyak dibanding penduduk yang tinggal di wilayah pedesaan. Secara geografis Indonesia terletak pada rangkaian cincin api yang membentang sepanjang lempeng pasifik yang merupakan lempengan tektonik paling aktif di dunia. Zona ini memberikan kontribusi sebesar hampir $90 \%$ dari kejadian gempa di bumi dan hampir semuanya merupakan gempa besar di dunia (Amri, 2016).

Melihat wilayah Indonesia yang sangat luas dan juga jumlah penduduk yang semakin bertambah serta lokasi Indonesia berada pada lokasi rawan bencana gempa, maka Indonesia memerlukan kemampuan untuk penanganan bencana yang handal. Selain upaya pencegahan, penanganan kejadian bencana itu sendiri sangat diperlukan (Maarif, 2016).

Belum lama telah terjadi gempa di Lombok, kejadian Gempabumi Pulau Lombok dimulai pada tanggal 29 Juli 2018 (M6.4). Wilayah Lombok, Provinsi Nusa tenggara barat, terletak pada kawasan tektonik aktif yang dikelilingi oleh beberapa sumber gempa, yaitu diantara Zona Back Arc Thrust di wilayah utara, megathrust di Selatan, dan sistem sesar geser di sisi barat dan timurnya (Pradono, 2018). Kejadian gempabumi di DKI Jakarta pada tahun 2007 dan 2009 mengingatkan kembali perlunya mempersiapkan bangunan agar kuat menahan gaya gempa. Intensitas gempa pada kedua gempa tersebut diskalakan pada MMI IV-V.

Kedua kejadian tersebut menimbulkan kepanikan pada penghuni gedung akibat guncangan yang cukup signifikan. Beberapa gedung bertingkat mengalami kerusakan, walaupun dikategorikan sebagai kerusakan nonstruktural. Kerusakan yang terjadi meliputi retak diagonal pada dinding, jatuhnya plafon, retaknya lantai dilatasi, dan kerusakan lain yang terlihat mata. Kerusakan ini tidak merusak struktur bangunan, yaitu kolom, balok, pelat lantai, dan dinding struktur ( Pradono, 2017).

Walaupun gedung-gedung di DKI Jakarta sudah melalui pemeriksaan desain yang sangat ketat oleh pemerintah. Tetapi setelah desain disetujui, pelaksanaan pembangunan gedung tidak menjadi tanggung jawab pemerintah lagi untuk mengawasi. Kurangnya pengawasan berpotensi terhadap terjadinya perbedaanperbedaan dari desain semula. Oleh sebab itu diperlukan sebuah metode untuk mengkaji kerentanan gedung-gedung bertingkat di DKI Jakarta dengan tingkat ancaman gempabumi sesuai dengan yang dikeluarkan oleh Kementerian Pekerjaan Umum (Pradono, 2017). Sehingga salah satu data yang diperlukan untuk kajian tersebut adalah data tulangan pada kolom di Gedung bertingkat yang akan diukur adalah gedung BPPT Thamrin sebagai salah satu gedung bertingkat yang terletak pada pusat Jakarta.

\subsection{Tujuan}

Pengukuran ini dimaksudkan untuk mengetahui jumlah tulangan, diameter tulangan, dan selimut beton rata-rata dari kolom. Hasil pengukuran tersebut akan digunakan untuk kajian kerentanan gempa bumi pada gedung bertingkat.

\section{METODA PENELITIAN}

Sebelumnya Penelitian ini telah dilakukan pengamatan lapangan untuk menentukan titik sampel yang akan diukur, selanjutnya melakukan survei untuk mendapatkan data tulangan yang diperlukan dengan alat covermeter elektromagnetik yaitu pada kegiatan kajian kerentanan gedung bertingkat terhadap gempabumi. Metode penelitian ini adalah melakukan studi literatur dari berbagai sumber dan mengolah hasil data survei yang telah ada sebelumnya.

\section{HASIL DAN PEMBAHASAN}

\subsection{Profometer}

Profometer merupakan perangkat yang canggih untuk mencari lokasi tulangan dengan tanpa merusak serta untuk mengukur selimut beton dan diameter batang, yang menggunakan prinsip arus eddy dengan induksi pulsa sebagai metode pengukurannya. Di samping untuk mendeteksi diameter tulangan secara akurat sampai tingkat milimeter dengan hanya satu prosedur pengukuran, alat ukur selimut profometer bisa mengirimkan data yang terukur ke sebuah PC. Profometer menggunakan prinsip kerja alat electromagnetik didasarkan pada pengukuran perubahan medan magnet yang disebabkan oleh tulangan yang tertanam di dalam beton (Hariwarsianto, 2008).

Profometer dioperasikan dengan baterai atau listrik, terdiri dari sebuah detektor, alat ukur, dan kabel penghubung. Permukaan beton dipindai dengan detektor yang tetap ditempelkan pada permukaan beton sementara itu alat pengukur digital menunjukkan posisi tulangan terdekat. Jika tulangan yang diperiksa tidak terlalu banyak, dimungkinkan untuk memetakan seluruh tulangan yang terdekat ke permukaan pada seluruh bidang yang diperiksa. Dimungkinkan untuk menentukan posisi tulangan yang tumpang tindih. Untuk ketelitian yang maksimal, maka gangguan-gangguan 
yang disebabkan oleh tulangan yang lain atau bahan-bahan magnetik lainnya harus dihindari.

Pengukuran ketebalan selimut beton dan perkiraan jarak tulangan dengan alat covermeter elektromagnetik (profometer) dalam suatu struktur beton terpasang dilakukan terutama untuk memverifikasi antara perencanaan dengan hasil pengerjaan di lapangan. Beberapa alat sejenis dengan penambahan aplikasi tertentu dapat digunakan untuk mengkonfirmasikan perkiraan diameter tulangan dalam beton. Sesuatu medan elektromagnetik dihasilkan oleh detektor, ketika sebuah tulangan atau benda logam lainnya berada dalam medan ini, maka arah medan elektromagnetik akan terganggu. Gangguan yang terjadi akibat adanya unsur logam tersebut menyebabkan perubahan pada kekuatan medan elektromagnetik yang dideteksi oleh detektor dan ditunjukkan oleh alat ukur. Arah dan kedalaman logam tersebut kedua-duanya mempengaruhi pembacaan alat ukur, sehinggga dapat mengetahui lokasi dan posisi tulangan. Tebal selimut beton dapat juga ditentukan apabila telah dilakukan suatu kaliberasi yang sesuai untuk ukuran-ukuran tertentu dari tulangan dan bahan-bahan yang diselidiki (Surat Edaran Menteri PUPR No. 21/SE/M/2015).
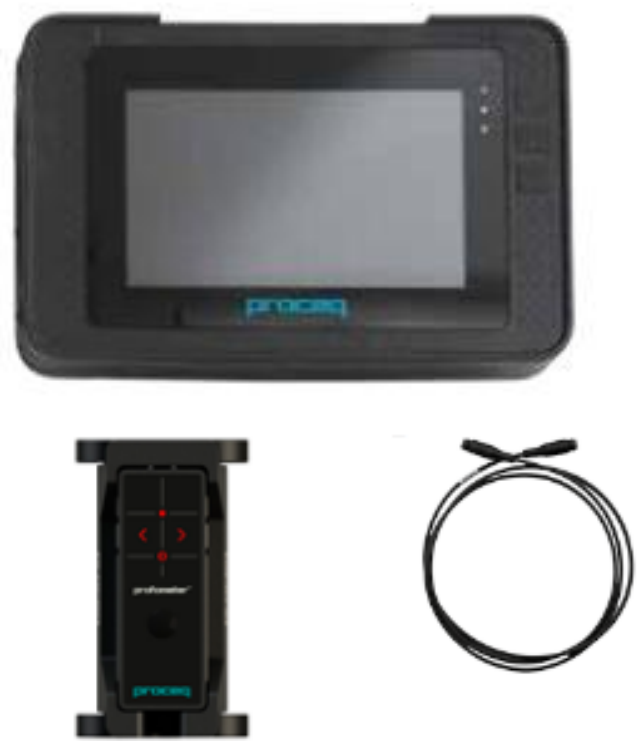

Gambar 1. Profometer

(Sumber: Profometer PM600/PM630 Operating Instructions)

\subsection{Hasil pengukuran dengan Profometer}

Gedung terdiri dari beberapa elemen struktur utama seperti kolom, balok, dan pelt lantai. Elemen - elemen struktur tersebut didesain sedemikian rupa untuk memenuhi syarat kekuatan dan syarat layan. Meskipun telah direncanakan dengan baik terkadang dalam pelaksanaannya terdapat perubahan baik dalam penerapan mix design maupun saat proses pengecoran (Edy, 2015). Mengingat struktur kolom adalah batang vertikal dari rangka struktur yang memikul beban dari balok (SNI-03-2847-2002) maka kajian ini elemen kolom menjadi fokusnya.

Pengukuran kolom bangunan dilakuan dengan covermeter elektromagnetik yaitu profometer, pengukuran ini mendapatkan beberapa data yang akan digunakan untuk analisis kerentanan bangunan bertingkat terhadap bencana gempabumi. Gempabumi sendiri merupakan fenomena alam yang akan terjadi pada tempat dan waktu tertentu dan dapat berulang pada lokasi yang sama dengan perioda ulang tertentu. Gempa yang berbahaya bagi bangunan adalah gempa yang diakibatkan oleh pergerakan kulit bumi, yang dikenal dengan gempa tektonik. Pergerakan kulit bumi biasanya terjadi secara mendadak yang diakibatkan terlepasnya enersi yang ditahan oleh kulit bumi yang saling bergesekan atau berbenturan satu dengan yang lainnya. Enersi yang dilepaskan akan merambat ke segala penjuru dengan kecepatan rambat yang tergantung pada kondisi tanah. Besar kecilnya energi gempa yang melanda bangunan akan sangat tergantung pada kedalaman pusat gempa, media tanah yang dilalui, jarak dari pusat gempa terhadap bangunan, dan jenis dan kualitas bangunan. Getaran gelombang gempa yang sangat berbahaya adalah gelombang pendek, walaupun akhir-akhir ini pada beberapa peristiwa, gelombang panjang telah memberikan dampak yang cukup berbahaya, seperti yang terjadi di Kobe. Gaya Gempa diasumsikan akan bekerja mendatar pada elevasi lantai bangunan, dan biasa dikenal dengan sebutan gaya lateral (Winarsih, 2010). Oleh karena itu kajian kerentanan gedung bertingkat terhadap gempabumi sangat penting agar dapat mengetahui kondisi bangunan setelah terjadinya gempabumi.

Kerusakan yang terjadi pada bangunan akibat bencana gempabumi tidak dapat ditentukan berdasarkan besarnya skala Richter suatu gempa yang terjadi. Tingkat kerusakan lebih ditentukan oleh jarak pusat gempa ke lokasi bangunan dan kondisi tanah setempat. Faktor lainnya adalah perencanaan dan detil bangunan yang baik serta rambatan gelombang gempa pada batuan dasar dan tanah akan menyebabkan percepatan yang sampai pada bangunan yang berbeda juga sehingga efeknya juga berbeda. Banyak gedung bertingkat yang mengalami kerusakan yang cukup parah akibat gempa. Kerusakan tersebut terutama terjadi karena kegagalan struktur pendukung 
bangunan tersebut, yaitu kolom-kolom yang rusak atau patah karena kesalahan perencanaan ataupun pelaksanaannya. Kolom meneruskan beban-beban dari elevasi atas ke elevasi yang lebih bawah hingga akhirnya sampai ke tanah melalui fondasi jadi keruntuhan pada satu kolom merupakan lokasi kritis yang akan menyebabkan runtuhnya lantai yang bersangkutan, dan juga runtuh batas total seluruh strukturnya (Wibowo, 2007).

Berikut koordinat kolom Gedung 2 BPPT yang akan dilakukan pengukuran dengan profometer pada gambar 2 di bawah ini.

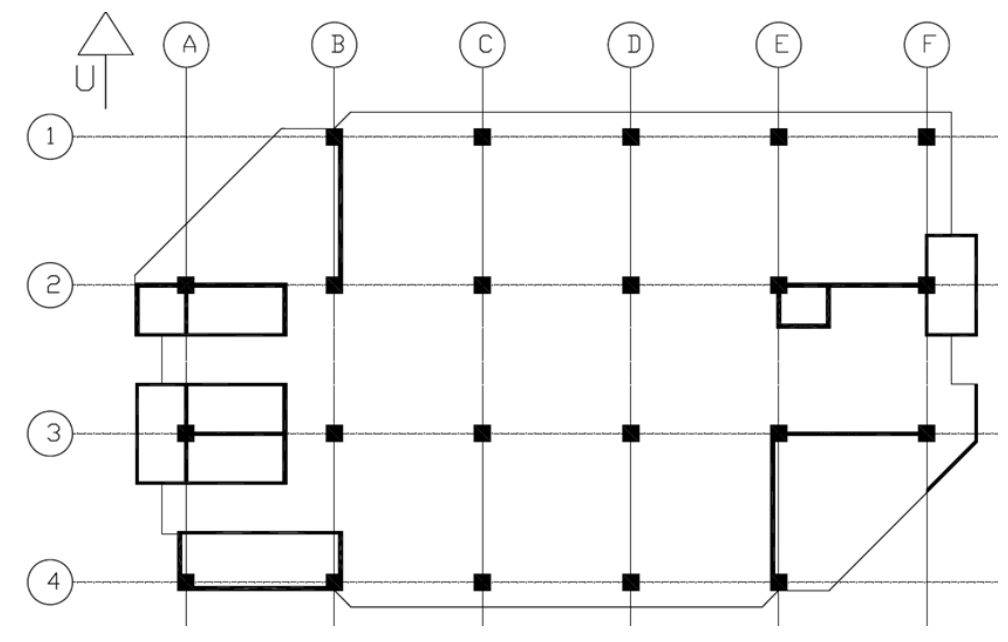

Gambar 2. Koordinat kolom Gedung 2 BPPT

Data yang diperoleh adalah data koordinat kolom, bentuk kolom, panjang sisi kolom, diameter tulangan, jumlah tulangan, dan selimut benton rata-rata. Setelah melakukan pengukuran tulangan dengan alat profometer diperoleh data tulangan pada Gambar 2.
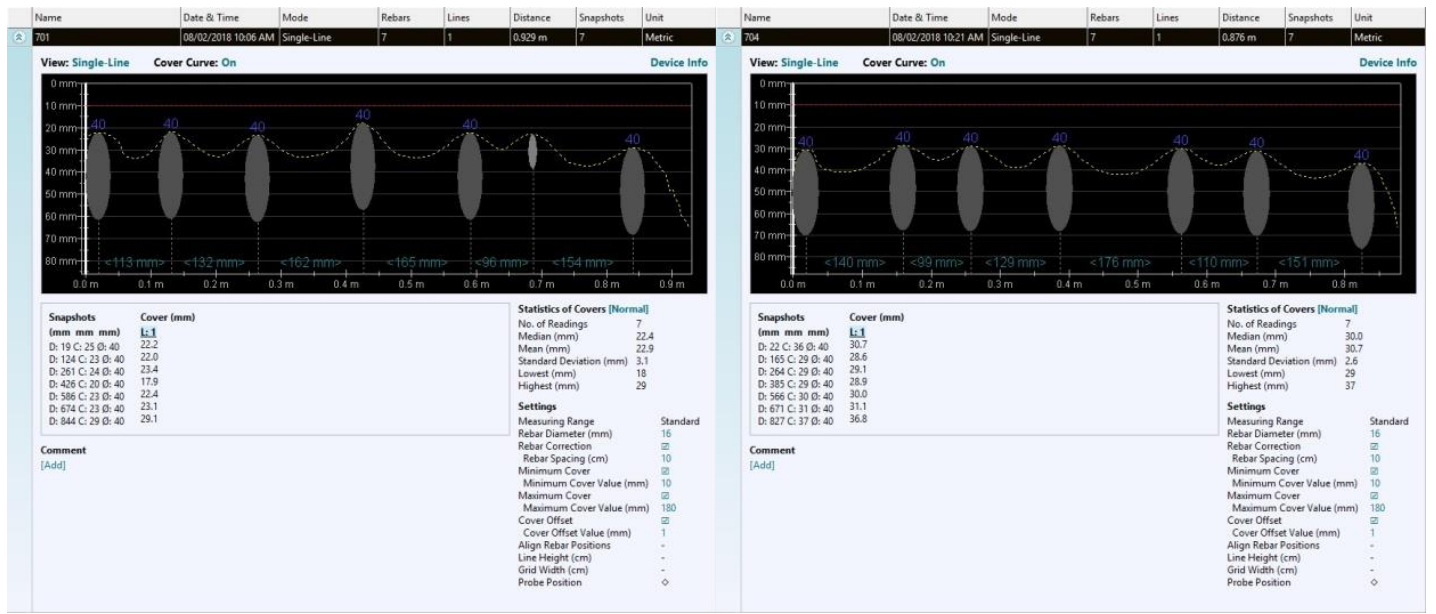

Gambar 3. Hasil Data Tulangan yang Diperoleh dari Pengukuran dengan Profometer

Pada gedung BPPT dilakukan pengukuran pada lantai $3,7,12,18$, dan 22. lantai tersebut merupakan sampel yang mewakili perubahan dimensi pada gedung tersebut. Gambar 3 merupakan sebagian dari hasil pengukuran profometer. Pengukuran beberapa sampel kolom yang akan mewakili struktur bangunan yaitu kolom sisi atau tepi, kolom tengah, kolom sudut, dan jika ada dinding struktur. Dimulai dari lantai 3 diambil ada 10 sampel koordinat kolom yang diambil terdiri dari kolom dan dinding struktur, dari pengukuran diperoleh data seperti pada tabel 1 di bawah ini, koordinat kolom E1 merupakan sampel kolom tepi. Kolom tengah diwakili oleh koordinat kolom C3, sedangkan kolom sudut diwakili oleh koordinat kolom F1 serta dinding struktur diwakili koordinat FE, E23, IV, V, VI, IX-X, dan XI. Dari data yang diperoleh dapat disimpulkan untuk lantai 3 terdapat ukuran kolom $100 \times 100 \mathrm{~cm}$, diameter tulangan 40 , dan banyaknya tulangan yang mewakili dua sisi kolom yaitu 12 dan 12 (jumlah tulangan 44). 
Tabel 1. Hasil Pengukuran Kolom Lantai 3 dengan Profometer

\begin{tabular}{|c|c|c|c|c|c|c|c|c|c|c|}
\hline \multirow[t]{2}{*}{ No } & \multirow[t]{2}{*}{ Kolom } & \multirow[t]{2}{*}{ Bentuk } & \multirow{2}{*}{$\begin{array}{l}\text { H/B1 } \\
\text { (cm) }\end{array}$} & \multicolumn{2}{|c|}{ Tulangan } & \multirow{2}{*}{$\begin{array}{c}\text { Selimut } \\
\text { Beton } \\
\text { Rata- } \\
\text { rata } \\
(\mathrm{mm})\end{array}$} & \multirow{2}{*}{$\begin{array}{l}\text { A/B2 } \\
(\mathrm{cm})\end{array}$} & \multicolumn{2}{|c|}{ Tulangan } & \multirow{3}{*}{$\begin{array}{l}\text { Selimut } \\
\text { Beton } \\
\text { Rata- } \\
\text { rata } \\
(\mathrm{mm}) \\
30\end{array}$} \\
\hline & & & & $\begin{array}{c}\text { Diameter } \\
(\mathrm{mm})\end{array}$ & Jumlah & & & $\begin{array}{c}\text { Diameter } \\
(\mathrm{mm})\end{array}$ & Jumlah & \\
\hline 1 & C3 & Persegi & 100 & 40 & 12 & 31 & 100 & 40 & 12 & \\
\hline 2 & FE & Dinding & 100 & - & 8 & 60 & - & - & - & - \\
\hline 3 & E2-3 & Dinding & - & - & - & - & 100 & - & 8 & 60 \\
\hline 4 & IV & Dinding & - & - & - & - & 100 & 40 & 9 & 42 \\
\hline 5 & V & Dinding & 80 & - & 6 & 64 & 100 & 40 & & \\
\hline 6 & VI & Dinding & - & - & - & - & 100 & 40 & 10 & 43 \\
\hline 7 & $\mathrm{~F} 1$ & Persegi & 100 & 40 & 13 & 30 & 100 & 40 & 12 & 33 \\
\hline 8 & E1 & Persegi & 100 & 40 & 12 & 30 & 100 & 40 & 12 & 28 \\
\hline 9 & IX-X & Dinding & 100 & - & 9 & 55 & - & - & - & - \\
\hline 10 & XI & Dinding & 100 & 40 & 9 & 45 & - & - & - & - \\
\hline
\end{tabular}

Selanjutnya, dilakukan pengukuran pada lantai 7, diperoleh 11 kordinat sampel kolom yang terdiri dari kolom dan dinding struktur. Koordinat kolom D1, C3, dan F1, sedangkan koordinat E2-3, EF2, F2-3, VI, F2-3VII, F2-3VIII, EF3, E3-4, dan B1-2 merupakan dinding struktur.
Pada tabel 2 diperoleh koordinat kolom D1 merupakan sampel kolom tepi. Kolom tengah diwakili oleh koordinat kolom C3 sedangkan kolom sudut diwakili oleh koordinat kolom F1 serta dinding struktur diwakili koordinat E2-3, EF2, F2-3VI, F2-3VII, F2-3VIII, EF3, E3-4, dan B1-2.

Tabel 2. Hasil Pengukuran Kolom Lantai 7 dengan Profometer

\begin{tabular}{|c|c|c|c|c|c|c|c|c|c|c|}
\hline \multirow[t]{2}{*}{ No } & \multirow[t]{2}{*}{ Kolom } & \multirow[t]{2}{*}{ Bentuk } & \multirow{2}{*}{$\begin{array}{l}\text { H/B1 } \\
\text { (cm) }\end{array}$} & \multicolumn{2}{|c|}{ Tulangan } & \multirow{2}{*}{$\begin{array}{c}\text { Selimut } \\
\text { Beton } \\
\text { Rata- } \\
\text { rata } \\
(\mathrm{mm})\end{array}$} & \multirow{2}{*}{$\begin{array}{l}\text { A/B2 } \\
(\mathrm{cm})\end{array}$} & \multicolumn{2}{|c|}{ Tulangan } & \multirow{2}{*}{$\begin{array}{c}\text { Selimut } \\
\text { Beton } \\
\text { Rata- } \\
\text { rata } \\
(\mathrm{mm})\end{array}$} \\
\hline & & & & $\begin{array}{l}\text { Diameter } \\
(\mathrm{mm})\end{array}$ & Jumlah & & & $\begin{array}{l}\text { Diameter } \\
(\mathrm{mm})\end{array}$ & Jumlah & \\
\hline 1 & D1 & Persegi & 95 & 40 & 10 & 38 & 100 & 40 & 10 & 37 \\
\hline 2 & C3 & Persegi & 100 & 40 & 11 & 33 & 100 & 40 & 10 & 24 \\
\hline 3 & F1 & Persegi & 100 & 40 & 11 & 18 & 100 & 40 & 11 & 23 \\
\hline 4 & E2-3 & Dinding & - & - & - & - & 100 & - & 8 & 58 \\
\hline 5 & EF2 & Dinding & - & - & - & - & 100 & 33 & 9 & 52 \\
\hline 6 & F2-3-VI & Dinding & 100 & 23 & 7 & 55 & - & - & - & - \\
\hline 7 & F2-3-VII & Dinding & - & - & - & - & 100 & 40 & 11 & 54 \\
\hline 8 & F2-3-VIII & Dinding & - & - & - & - & 100 & - & 10 & 53 \\
\hline 9 & EF3 & Dinding & 100 & 40 & 9 & 62 & - & - & - & - \\
\hline 10 & E34 & Dinding & - & - & - & - & 100 & 40 & 7 & 55 \\
\hline 11 & B1-2 & Dinding & - & - & - & - & 100 & 40 & 9 & 50 \\
\hline
\end{tabular}

Dari data lantai 8 mempunyai ukuran kolom 100 x $100 \mathrm{~cm}$, diameter tulangan 40, dan banyaknya tulangan yang mewakili dua sisi kolom yaitu 12 dan 12 (jumlah tulangan 44). Pada lantai 12, diperoleh 11 kordinat sampel kolom yang terdiri dari kolom dan dinding struktur. 
Tabel 3. Hasil Pengukuran Kolom Lantai 12 dengan Profometer

\begin{tabular}{|c|c|c|c|c|c|c|c|c|c|c|}
\hline \multirow[t]{2}{*}{ No } & \multirow[t]{2}{*}{ Kolom } & \multirow[t]{2}{*}{ Bentuk } & \multirow{2}{*}{$\begin{array}{l}\text { H/B1 } \\
\text { (cm) }\end{array}$} & \multicolumn{2}{|c|}{ Tulangan } & \multirow{2}{*}{$\begin{array}{c}\text { Selimut } \\
\text { Beton } \\
\text { Rata- } \\
\text { rata } \\
(\mathrm{mm})\end{array}$} & \multirow{2}{*}{$\begin{array}{l}\text { A/B2 } \\
\text { (cm) }\end{array}$} & \multicolumn{2}{|c|}{ Tulangan } & \multirow{2}{*}{$\begin{array}{l}\text { Selimut } \\
\text { Beton } \\
\text { Rata- } \\
\text { rata } \\
(\mathrm{mm})\end{array}$} \\
\hline & & & & $\begin{array}{c}\text { Diameter } \\
(\mathrm{mm})\end{array}$ & Jumlah & & & $\begin{array}{l}\text { Diameter } \\
(\mathrm{mm})\end{array}$ & Jumlah & \\
\hline 1 & $\mathrm{~F} 1$ & Persegi & 96 & 40 & 7 & 31 & 96 & 40 & 7 & 21 \\
\hline 2 & D1 & Persegi & 96 & 40 & 6 & 23 & 96 & 40 & 7 & 36 \\
\hline 3 & D2 & Persegi & 96 & 40 & 7 & 47 & 96 & 40 & 6 & 35 \\
\hline 4 & E3-4 & Dinding & 100 & 40 & 8 & 48 & 100 & 32 & 7 & 55 \\
\hline 5 & E2-2,5 & Dinding & 100 & - & 6 & 69 & 100 & - & - & - \\
\hline 6 & EF & Dinding & - & - & - & - & 100 & 40 & 11 & 40 \\
\hline 7 & F2 & Dinding & - & - & - & - & 100 & - & 8 & 61 \\
\hline 8 & F- & Dinding & - & - & - & - & 100 & - & 8 & 61 \\
\hline 9 & F2-3 & Dinding & - & - & - & - & 100 & 18 & 11 & 56 \\
\hline 10 & EF3 & Dinding & 100 & 27 & 11 & 59 & - & - & - & - \\
\hline 11 & B1-2 & Dinding & - & - & - & - & 100 & 40 & 9 & 60 \\
\hline
\end{tabular}

Pada tabel 3 diperoleh koordinat kolom D1 merupakan sampel kolom tepi. Kolom tengah diwakili oleh koordinat kolom D2, sedangkan kolom sudut diwakili oleh koordinat kolom F1 serta dinding struktur diwakili koordinat E3-4, E22, EF, F2, F-, F2-3,EF3, B1-2. Dari data yang diperoleh dapat disimpulkan untuk lantai 12 terdapat ukuran kolom $90 \times 90 \mathrm{~cm}$, diameter tulangan 40 , dan banyaknya tulangan yang mewakili dua sisi kolom yaitu 9 dan 9 (jumlah tulangan 32). Lantai 18, diperoleh 12 kordinat sampel kolom yang terdiri dari kolom dan dinding struktur.

Tabel 4. Hasil Pengukuran Kolom Lantai 18 dengan Profometer

\begin{tabular}{|c|c|c|c|c|c|c|c|c|c|c|}
\hline \multirow[t]{2}{*}{ No } & \multirow[t]{2}{*}{ Kolom } & \multirow[t]{2}{*}{ Bentuk } & \multirow{2}{*}{$\begin{array}{l}\text { H/B1 } \\
(\mathrm{cm})\end{array}$} & \multicolumn{2}{|c|}{ Tulangan } & \multirow{2}{*}{$\begin{array}{l}\text { Selimut } \\
\text { Beton } \\
\text { Rata- } \\
\text { rata } \\
(\mathrm{mm})\end{array}$} & \multirow{2}{*}{$\begin{array}{l}\text { A/B2 } \\
(\mathrm{cm})\end{array}$} & \multicolumn{2}{|c|}{ Tulangan } & \multirow{2}{*}{$\begin{array}{c}\text { Selimut } \\
\text { Beton } \\
\text { Rata-rata } \\
(\mathrm{mm})\end{array}$} \\
\hline & & & & $\begin{array}{l}\text { Diameter } \\
(\mathrm{mm})\end{array}$ & Jumlah & & & $\begin{array}{c}\text { Diameter } \\
(\mathrm{mm})\end{array}$ & Jumlah & \\
\hline 1 & C3 & Persegi & - & - & - & - & 90 & 40 & 9 & 30 \\
\hline 2 & C2 & Persegi & 90 & 40 & 11 & 25 & - & - & - & - \\
\hline 3 & A4 & Persegi & 90 & 40 & 9 & 32 & 90 & 40 & 9 & 30 \\
\hline 4 & B4 & Persegi & 40 & 40 & 4 & 30 & 90 & 40 & 9 & 29 \\
\hline 5 & B2 & Dinding & - & - & - & - & 100 & - & 11 & 55 \\
\hline 6 & IV & Dinding & 100 & - & 9 & 58 & - & - & - & - \\
\hline 7 & V & Dinding & - & - & - & - & 100 & 40 & 9 & 52 \\
\hline 8 & VI & Dinding & - & - & - & - & 100 & 40 & 9 & 55 \\
\hline 9 & VII & Dinding & 100 & - & 7 & 59 & 100 & - & - & - \\
\hline 10 & VIII & Dinding & - & - & - & - & 100 & 40 & 9 & 46 \\
\hline 11 & E3-4 & Dinding & - & - & - & - & 100 & 40 & 8 & 49 \\
\hline 12 & EF3 & Dinding & 100 & - & 6 & 57 & - & - & - & \\
\hline
\end{tabular}

Pada tabel 4 diperoleh koordinat kolom B4 merupakan sampel kolom tepi. Kolom tengah diwakili oleh koordinat kolom C2 dan C3. Sedangkan kolom sudut diwakili oleh koordinat kolom A4 serta dinding struktur diwakili koordinat B2, IV, V, VI, VII, VIII, E3-4, dan EF3. Dari data yang diperoleh dapat disimpulkan untuk lantai 18 terdapat ukuran kolom $90 \times 90$ $\mathrm{cm}$, diameter tulangan 40 , dan banyaknya tulangan yang mewakili dua sisi kolom yaitu 9 dan 9 (jumlah tulangan 32).

Pengukuran pada lantai 22, diperoleh 12 kordinat sampel kolom yang terdiri dari kolom dan dinding struktur. Pada tabel 5 di bawah ini 
diperoleh koordinat kolom E1 merupakan sampel kolom tepi. Kolom tengah diwakili oleh koordinat kolom C3 dan D3, sedangkan kolom sudut diwakili oleh koordinat kolom F1 serta dinding struktur diwakili koordinat $\mathrm{V}, \mathrm{VI}, \mathrm{VII}$, VIII, IX, X, XI, dan XII. Dari data yang diperoleh dapat disimpulkan untuk lantai 22 terdapat ukuran kolom $80 \times 80 \mathrm{~cm}$, diameter tulangan 40 , dan banyaknya tulangan yang mewakili dua sisi kolom yaitu 7 dan 7 (jumlah tulangan 24).

Tabel 5. Hasil Pengukuran Kolom Lantai 22 dengan Profometer

\begin{tabular}{|c|c|c|c|c|c|c|c|c|c|c|}
\hline \multirow[t]{2}{*}{ No } & \multirow[t]{2}{*}{ Kolom } & \multirow[t]{2}{*}{ Bentuk } & \multirow{2}{*}{$\begin{array}{l}\text { H/B1 } \\
\text { (cm) }\end{array}$} & \multicolumn{2}{|c|}{ Tulangan } & \multirow{3}{*}{$\begin{array}{c}\text { Selimut } \\
\text { Beton } \\
\text { Rata- } \\
\text { rata } \\
(\mathrm{mm})\end{array}$} & \multirow{2}{*}{$\begin{array}{l}\text { A/B2 } \\
(\mathrm{cm})\end{array}$} & \multicolumn{2}{|c|}{ Tulangan } & \multirow{3}{*}{$\begin{array}{c}\text { Selimut } \\
\text { Beton } \\
\text { Rata- } \\
\text { rata } \\
(\mathbf{m m}) \\
29\end{array}$} \\
\hline & & & & $\begin{array}{c}\text { Diameter } \\
(\mathrm{mm})\end{array}$ & Jumlah & & & $\begin{array}{c}\text { Diameter } \\
(\mathrm{mm})\end{array}$ & Jumlah & \\
\hline 1 & C3 & Persegi & 80 & - & - & & 80 & 40 & 7 & \\
\hline 2 & D3 & Persegi & 80 & 40 & 7 & 39 & - & - & - & - \\
\hline 3 & F1 & Persegi & 80 & 40 & 5 & 20 & 80 & 37 & 5 & 27 \\
\hline 4 & E1 & Persegi & 80 & 40 & 7 & 41 & 80 & 40 & 7 & 32 \\
\hline 5 & V & Dinding & 100 & 40 & 7 & 52 & - & - & - & - \\
\hline 6 & VI & Dinding & - & - & - & - & 100 & - & 8 & 54 \\
\hline 7 & VII & Dinding & - & - & - & - & 100 & - & 7 & 55 \\
\hline 8 & VIII & Dinding & 80 & 28 & 5 & 55 & - & - & - & - \\
\hline 9 & IX & Dinding & - & - & - & - & 100 & 40 & 9 & 46 \\
\hline 10 & $\mathrm{X}$ & Dinding & 100 & 40 & 9 & 55 & - & - & - & - \\
\hline 11 & XI & Dinding & - & - & - & - & 100 & - & 9 & 61 \\
\hline 12 & XII & Dinding & - & - & - & - & 100 & - & 9 & 53 \\
\hline
\end{tabular}

Beberapa faktor yang mempengaruhi pengukuran tulangan ini (Madutujuh, 2013) adalah sebagai berikut:

1. Tebal selimut beton yang tidak seragam

2. Plesteran tambahan

3. Jarak tulangan yang tidak seragam

4. tulangan sengkang dan tulangan arah tegak lurus

5. Overlap antar tulangan

6. Posisi final profometer ( trial and error).

Selanjutnya, hasil pengukuran ini akan digunakan untuk analisis data kajian kerentanan gedung bertingkat terhadap gempabumi.

\section{KESIMPULAN}

Berdasarkan Pengukuran tulangan Gedung 2 BPPT, maka dapat disimpulkan beberapa hal sebagai berikut:

1. Ada 3 tipe kolom, yaitu:

a. Ukuran $80 \times 80 \mathrm{~cm}$ dengan diameter tulangan $40 \mathrm{~mm}$ tulangan sebanyak 24 buah,

b. Ukuran $90 \times 90 \mathrm{~cm}$ dengan diameter tulangan $40 \mathrm{~mm}$ tulangan sebanyak 32 buah, c. Ukuran $100 \times 100 \mathrm{~cm}$ dengan diameter tulangan $40 \mathrm{~mm}$ tulangan sebanyak 44 buah.

2. Semakin banyaknya sampel kolom yang dipindai, semakin detail analisis data untuk digunakan sebagai kajian kerentanan gedung BPPT terhadap gempabumi.

\section{DAFTAR PUSTAKA}

Amri, M. R., Yulianti, G., Yunus, R., Wiguna, S., Adi, A. W., Ichwana, A. N., Randongkir, R. E., Septian, R. T. 2016. RBI Risiko Bencana Indonesia. Direktorat Pengurangan Risiko Bencana, BNPB.

Edy, Akmaluddin, dan Kencanawati, N. N. 2015. Evaluasi Kekuatan Elemen Struktur Kolom Menggunakan Peralatan NTD. Jurnal Sains Teknologi \& Lingkungan, Vol. 1, No. 2, ISSN: 2477-0329, E-ISSN: 2477-0310, Hal. 38-44.

Maarif, S., Kinseng, R. A., dan Pramono, R. 2016. Dimensi Sosial Dalam Penanganan Bencana ( Studi Kasus Penanganan Gempabumi di Kecamatan Pangalengan, Kabupaten Bnadung). Jurnal Riset 
Kebencanaan Indonesia, vol. 2, No. 2, Oktober 2016: 95-105.

Madutujuh, N., Prawiranegara, J., Ariadit, dan Natalius, D. 2013. Audit Kekuatan Struktur dan Perkuatan Struktur Pasca Gempa. Seminar Hastag, April 2013.

Hariwarsianto dan Narayudha, M. 2008. Investigasi Non Destruktif dengan Profometer. Teknik, Vol. 29 No. 3 Tahun 2008, ISSN 0852-1697.

Pradono, M. H. 2017. Kajian Kerentanan Gempabumi Pada Sekolah dan Pasar Di DKI Jakarta Menggunakan Metode Kaji Cepat. Jurnal Alami, Vol. 1, No. 1, Tahun 2017. Hal: 49-54.

Pradono, M. H. 2018. Kajian Kerentanan Bangunan Pasca Gempa Lombok 5 Agustus 2018. Jurnal Alami, Vol. 2, No. 2, Tahun 2018. Hal: 82-88.

Profometer PM600/PM630 Operating Instructions.

Surat Edaran Menteri Pekerjaan Umum dan Perumahan Rakyat Nomor: 21/SE/M/2015, Pedoman Pengukuran Ketebalan Selimut Beton dengan Covermeter Elektromagnetik.

Winarsih, T. 2010. Asesmen Kekuatan Struktur Bangunan Gedung, Studi Kasus: Bangunan Gedung Unit Gawat Darurat (UGD) dan Administrasi Rumah Sakit Umum Daerah (RSUD) Banyudono, Kabupaten Boyolali. Program Studi Teknik Sipil, Universitas Sebelas Maret Surakarta.

Wibowo, F. X. N., Arfiadi, Y., dan Handayani, F. D. 2007. Perkuatan Kolom Miring Akibat Gempa Bumi. Konferensi Nasional Teknik Sipil 1, UniVERSITAS Atma Jaya Yogyakarta, 11-12 Mei 2007, Hal: 435442. 